Paul R. Mullins

Modupe Labode

Lewis C. Jones

Michael E. Essex

Alex M. Kruse

G. Brandon Muncy

\section{Consuming Lines of Difference: The Politics of Wealth and Poverty along the Color Line}

\begin{abstract}
Commentators on African American life have often focused on poverty, evaded recognition of African American wealth, and ignored the ways genteel affluence and impoverishment were constructed along turn-of-the-century color lines. Documentary research and archaeology at the Madam C.J. Walker home in Indianapolis, Indiana, illuminates how the continuum of wealth and poverty was defined and negotiated by one of African America's wealthiest early-20th-century entrepreneurs. The project provides an opportunity to compare the ways in which wealth was defined and experienced along the color line in the early 20th century, and how such notions of black affluence shaped racialized definitions of poverty and materiality.
\end{abstract}

\section{Respectable Wealth and the Color Line}

In May 1911, Sarah Walker moved into her new Indianapolis, Indiana, home, apparently determined to appoint it in a manner befitting one of America's most prominent entrepreneurs. Billing herself as "Madam C.J. Walker," Walker began selling her hair-care products and services within two days of reaching Indianapolis in February 1910, and her business rapidly increased its profits. After renting a home on North West Street in the heart of an emerging African American neighborhood, she and husband C. J. Walker purchased the commodious neighboring residence for $\$ 3,500.00$ (Indianapolis Star 1911a:5). The couple had a housewarming at their new 640 North West Street house less than two months after its purchase, and the local paper noted that the 150 guests found a "beautiful and recently remodeled home ... decorated with palms and cut flowers. Music was furnished by a harpist" (Indianapolis Star 1911b:34). The Walkers lavishly furnished their new home with Oriental rugs, gold-leafed furnishings, a Chickering grand piano, a Tiffany chandelier, and original art (Bundles 2001:143; Dudley 2006:82).

For some ideologues (including black and white observers alike), Walker's home threatened the ideological link between poverty and blackness, undercut preconceptions about black women's labor and materialism, and destabilized certain perceptions of a "respectable" black middle class rooted in social and labor discipline, family heritage, and patriarchy. For many people of color, though, material wealth had long been a consciously political statement that defined consumption as a consequential citizen right, and affluence as a reflection of African America's suitability to those rights. Madam Walker's home, business, consumption, and philanthropy made her a role model of "respectability" for African American women in Indianapolis and throughout the country. But she and other black commentators certainly did not ignore poverty, railing against racist labor and social barriers, counseling the poor on social and material discipline, or championing respectability in the face of poverty. In these discussions the tension between wealth and penury was a powerful mechanism framing African American materialism.

At the outset of the 20th century Madam Walker stood at the heart of such tensions. Born in 1867, Madam Walker spent most of her life as a laundress and domestic saddled by significant poverty. After securing exceptional wealth she devoted much of it to philanthropy, supporting a host of causes targeting impoverished African Americans, and she could well have found many living in Indianapolis's near-Westside. Madam Walker's home sat directly beside much more modest alley residences that differed quite radically from their neighbor's palatial house. Madam Walker's 12-room home had internal plumbing and steam heat, while her neighbors almost universally were using outhouses and pump wells, and along North West Street most residents continued to heat their homes with wood or coal. In 1910 Walker advertised space for boarders at her home, much like many of her wealthy and working-class neighbors, 
underscoring that "Mme. C.J. Walker has thrown open her beautifully furnished home to the up-to-date traveling public. Her home is modern, including heat" (Recorder 1910:4; Bundles 2001:105).

In 2009, archaeological excavations at Madam Walker's home examined the ca. 1912 factory she built in her backyard and the neighboring homes. This paper raises two issues, one focused on the ideological relationship between race and wealth, and the other a question of what black wealth "looks like" and why it takes certain forms. The former question of how race influences the social meanings of wealth is a nearly universal issue for scholars examining 20th-century America, if not much of the 19th century as well. Madam Walker moved into the North West Street home at the very moment the neighborhood became universally black, a rapid 10-year transition in which white residents left the neighborhood to be replaced by African Americans. During that transition, particular definitions of blackness became ideologically linked to poverty, and the relationship between race and materiality would eventually rationalize urban renewal projects that profoundly transformed urban America. After World War II Madam Walker's former neighborhood was part of a broad swath of the near-Westside that was labeled a slum to legitimize widespread black displacements, and subsequent commentators have tended to project that picture of a universally black and poor community back onto the whole of the 20th century. Rather than accept black poverty as an appropriate rhetorical lens to view 20th-century African American experience, this paper examines how observers constructed, negotiated, and evaded recognition of black affluence like that of Madam Walker. There certainly was genuine impoverishment in Indianapolis's near-Westside, but Madam Walker was simply a prominent example of the many affluent African Americans who undermined shallow presumptions of widespread black penury. African American consumers often used commodities to demonstrate their readiness for full citizenship and repudiate racist caricatures, and Madam Walker embraced the most costly of goods. African Americans materialized numerous, often-conflicting visions of consumer wealth that were complicated by class, social, and gendered interests, however, and sometimes lapsed into the very racialized ideologies they aspired to undermine (Dossett 2009:93-95). Some newly affluent African Americans confirmed their entrance into bourgeois society with ostentatious wealth; others avoided "excessive" shows of commodity wealth; and some championed a notion of "respectable consumption" that maintained existing class, status, and patriarchal distinctions in African American communities. A wide range of politics ran through all of those consumption patterns, but all of those political perceptions of consumption were linked to the color line.

The second issue around which this paper revolves is how scholars define impoverishment and wealth. For archaeologists, defining wealth is minimally a methodological challenge, but this also raises complicated questions about how 20th-century Americans and contemporary archaeologists alike should view black affluence. Madam Walker's short five-year occupation of the Indianapolis home left frustratingly little archaeological material culture that can be tightly dated to her residency, and in large part this is because her occupation of the home was so brief. Many of the home's consumer goods were very expensive commodities, however, unlikely to appear in archaeological deposits even over long occupations. This raises a methodological quandary of how to interpret such affluence in the absence of many archaeological artifacts and precisely what such affluence might have "looked like" in archaeological assemblages, which normally represent everyday material culture most clearly. Despite this challenge, excavated artifacts are never analyzed in a vacuum separate from other resources, and a rich range of resources documenting Walker's Indianapolis house and two subsequent New York homes provides an especially detailed material picture of her most costly goods. These records certainly do not provide a picture of Walker's entire material assemblage, but the fundamental archaeological implications revolve around how Walker's consumption illuminates the ways affluence was defined along the color line. Those definitions of affluence took many different material forms in African America, reflected in a vast range of archaeological patterns, but they almost always responded to dominant ideological visions of racialized poverty. Consumer goods were points of contestation over the definition of white and black, and for many 
African Americans that debate revolved around defusing poverty stereotypes, underscoring African American wealth, and demonstrating that affluence was not exclusive to whites.

\section{"Ambitious to Be Conventional": Affluence along the Color Line}

In 1911, Mary White Ovington's (1911:171) study of African Americans in New York City advanced a novel thesis on black materiality and civic identity, concluding that "[f]ew of New York's citizens are so American as the colored, few show so little that is unusual or picturesque." This picture of a mundane black materiality broke dramatically from xenophobic depictions of blacks, venturing that African America was committed to embracing the prosaic behavioral and material dimensions of citizenship. Ovington (1911:171) believed all significant ethnic distinctions had been quashed from African America, insisting that the typical African American New Yorker was "ambitious to be conventional in his manners, his customs, striving as far as possible to be like his neighbor - a distinctly American ambition." In the face of that prosaic picture, though, Ovington struggled with the social meanings of black affluence. On the one hand, Ovington (1911:188) divined activist implications in African American wealth, suggesting that affluence drove many African Americans to combat racism more assertively. She argued that "[a] comfortable income and the intelligence to enjoy the culture of a great city do not bring to the Negro any smug self-satisfaction; only a great responsibility toward the problem that moves through the world with his dark face." On the other hand, though, she argued that some African Americans considered affluence to signal acquiescence to racism. Ovington (1911:187) argued that in the eyes of African American neighbors "material success sometimes means a departure from the aggressive to the submissive attitude." In effect, black consumer affluence was won by bargaining with and even accepting certain dimensions of racist inequality.

Madam Walker certainly viewed her own wealth as a platform from which she could advocate for impoverished African Americans. In 1912 Walker arose at the National Negro Business League convention and acknowledged her heritage as a

woman that came from the cotton fields of the South. I was promoted from there to the wash-tub. Then I was promoted to the cook kitchen, and from there I promoted myself into the business of manufacturing hair goods and preparations (Bundles 2001:136).

As a sign of her success, she invoked her new factory and most recent material acquisitions, proclaiming from the convention floor that "I have built my own factory on my own ground, 38 by 208 feet. ... I own my own automobile and runabout." Walker saw such consumption serving broader activist interests, however, arguing that "my object in life is not simply to make money for myself or spend it on myself in dressing or running around in an automobile. But I love to use a part of what I make in trying to help others" (Bundles 2001:136).

Walker's declaration at the National Negro Business League convention voiced material ambitions and philanthropic interests shared by most of her audience, but much of that audience was likely unsettled by racialized poverty. For many of her fellow entrepreneurs and established black elite, impoverishment and residential segregation cast genteel black families, newly moneyed elite, and poor urban newcomers into the same neighborhoods and risked upsetting established social and material hierarchies (Gaines 1996:180). When Madam Walker arrived in Indianapolis's near-Westside in 1910, she found a community that was quickly becoming segregated along the color line, like most other northern cities into which Southern African Americans were migrating. De facto residential segregation forced Madam Walker and working-class African Americans to be neighbors, and inevitably this shaped how she and other African Americans defined various forms of wealth and poverty, divined its footing in racism, and chose to negotiate racially based impoverishment. Not all of her peers were eager to become philanthropists for the race, instead seeing themselves as social and behavioral models, or actually desiring insularity from the African American masses. Madam Walker, though, spent the last nine years of her life exceptionally affluent, and with that wealth she materially championed a host of African American causes targeting the poor, women, and education, even as she embraced ostentatious material affluence. Walker approached wealth as a visible material refutation of racist caricatures, embracing conspicuous material culture but seeing it as an example to African America that 
would "inspire them to do big things" (Bundles 2001:235). Many other African American elite would materialize their affluence in quite different forms, but all were compelled to define affluence in direct relation to poverty and in reference to the color line.

\section{Residential Segregation and the Color Line}

Through the late 19th century the spacious homes along Indianapolis's North West Street were all residences of whites, who included people born throughout the country, as well as a more modest number of European immigrants. Most of the homes, including Madam Walker's future residence, were built in the 1870s. The home at 640 North West Street first appeared in the city directory in 1874 , when it was the residence of Abel and Harriet Davis. The Davises were both born in New Hampshire, where Abel had been a farmer and produce dealer until about 1867, when he and Harriet first appear in Indianapolis's city directory. Indianapolis had rapidly expanded in the mid-19th century after railroads and the National Road arrived, and in the 1870s it again mushroomed as local industry and railroad business grew anew after the Civil War. Many newcomers like the Davises were drawn by entrepreneurial possibilities, and Abel Davis was the co-owner of a grocery store in Indianapolis until his death in 1906. In the $1880 \mathrm{~s}$ and 1890 s their neighbors included both relatively prosperous merchants and working-class people, ranging from shoemakers and carpenters to several seamstresses who were apparently working from the North West Street homes. None of those neighbors was African American.

When Madam Walker moved into 640 North West Street in 1911 she would find only two white neighbors in her block, and both would leave within two years. This underscores that the transformation from a white to a black neighborhood happened very rapidly between 1900 and 1910. In 1900, just under a third of the nearWestside's residents were black $(9.3 \%$ of the city's overall population was identified as black), and they were especially concentrated in pockets along Indiana Avenue and north of Indiana Avenue (Divita 1994:55; Thornbrough 2000:4). The Great Migration delivered a wave of black migrants to Indianapolis after the turn of the century, most coming from Southern border states like Kentucky. In 1900 there was not a single African American living in the homes alongside Abel and Harriet Davis, but in the subsequent decade whites moved out nearly universally, and a handful of rear lot lines became home to alley structures that increased the residential density.

Madam Walker made some architectural changes to her new home, but the house was distinguished less by its scale and architecture than its household material culture. The home's domestic goods included many exceptionally costly commodities, so the question is how the meaning of these specific things and the broader symbolism of black affluence were constructed by a range of commentators along and across the color line. Walker's North West Street home had drawing rooms with Oriental rugs and a Tiffany chandelier; the dining room featured a massive oak table, china cabinets, and stylish new wallpaper; and the library included a grand piano and a painting by William Edouard Scott (Dudley 2006:82). Any of these goods would have been quite uncommon in any Indianapolis household, and some are particularly noteworthy. The Scott painting, for instance, was among the most distinctive pieces of material culture in Madam Walker's new home. Born in Indianapolis, the African American artist William Scott attended the Chicago Art Institute between 1904 and 1908 and subsequently trained under Henry O. Tanner in France (Leininger-Miller 2000:12-13). In 1913 Scott had an exhibition in Indianapolis at the studio of his mentor, Otto Stark, and an anonymous group of African American residents purchased the painting Rainy Night, Etaples, and presented it to the Herron Art Institute in Indianapolis (Leininger-Miller 2000:13). It is not clear if Madam Walker were part of that group or commissioned the painting that graced her library, but artwork was among the costly decorative goods, and patronage of an African American artist almost certainly would have made the painting even more symbolically important.

Madam Walker's Chickering piano was made by one of America's most prominent piano producers (Kornblith 1985), and because pianos were powerful symbols of American domestic life and class ambition they were widely consumed across the color line (Roell 1994). Like many other commodities, their consumption in black households was often greeted with uneasiness. In 1879, for instance, a Vicksburg, Mississippi, 
paper alluded to pianos' symbolic power when it lamented that deceptive chromolithographs of black life in Kansas were making unrealistic material promises that were convincing African Americans to leave the South for Kansas. They took aim at a chromolithograph that portrayed

a picturesque cottage with gables, dormer windows and wide verandas. ... Through the open door of the kitchen the colored wife could be seen directing the servants and cooks who were preparing the evening meal. In the parlor, however, was the most enchanting feature, for at a grand piano was poised the belle of the household, and beside the piano where she was playing stood her colored lover, devouring her with his eyes while he abstractedly turned the leaves of her music (Journal of Negro History 1919:55).

When Madam Walker built a Harlem home in 1916, the house included a player organ that stretched from the floor to ceiling, as well as a gold-leafed Aeolian grand piano and several equally opulent gilded Victrolas (Bundles 2001:172). Pianos and music were likewise featured in the subsequent mansion she had constructed at Irvington-on-Hudson north of New York City in 1918. The Irvington mansion, known as Villa Lewaro, had a piano with a 24-karat gold-leaf finish, a player piano, and a $\$ 25,000$ pipe organ that was built into the house's walls (New York Times 1930:27, 1932:36). A significant part of pianos' appeal was their implication of wealth and social refinement, and most wealthy African American homes had a piano by the early 20th century (Fitts 2002:6). In 1908, W. E. B. Du Bois (1908:65) noted that Atlanta's "best" African American homes "are good-sized one and two-story homes, having bathrooms and water in the house, and in many cases gas and electric-bells. ... The parlors and some of the other rooms have tiled hearths, and there is usually a piano or organ in the home." A 1917 analysis recognized Chickering's class appeals, concluding that "advertisements of the Chickering Piano are evidently devised to represent the piano as an article of furniture in a home which is most sumptuously and tastefully furnished. We are left to draw the conclusion for ourselves that if persons with such elegant homes choose the Chickering it must be good enough for us" (Scott 1917:195).

Nevertheless, by the turn of the century pianos had become more accessible because of mass production and installment payment plans.
In 1910 William Archer (1910:160) noted in his tour of African American households that "[e]very home, without exception, had its piano, sometimes with open music on it." Archer was critical of how African Americans secured such funds, however, and in New Orleans one woman told him that such goods were purchased by parents who enlisted their children as laborers. She told Archer (1910:92):

[I]t isn't always - perhaps not generally-extreme poverty that makes the parents thus sacrifice their children. Often the children's earnings will go to pay the two or two-and-a-half dollars a month demanded for a piano on the instalment system. That instalment system is a great curse to the ignorant poor.

Ray Stannard Baker (1973:62) reached the same conclusion in 1904, arguing that in "the poorer Negro homes" he would find

\begin{abstract}
one or two rooms meanly furnished, but having in one corner a glittering cottage organ, or on the mantel shelf a glorified gilt clock. ... Often a Negro family will pay monthly for a year or so on some showy clock or chromo or music-box or decorated mirror-paying the value of it a dozen times over, only to have it seized when through sickness, or lack of foresight, they fail to meet a single note. Installment houses prey upon them.
\end{abstract}

Baker was among the numerous observers who felt compelled to neutralize the symbolism of mass-produced goods in African American households. For instance, William Archer (1910:160) was struck by the widespread African American embrace of stylish material goods in Charleston, South Carolina, noting that " $[\mathrm{t}] \mathrm{he}$ furniture was always modern and in excellent condition, with a great deal of plush about it. Much of it conveyed the impression (not uncommon in English villa residences) of being intended rather for show than use." Archer did detect some material aesthetics that revealed a black unwillingness or inability to reproduce stylistic norms. After dissecting wallpaper styles, the apparently universal presence of pianos, and similar details that upset black material caricatures, Archer found that "[i]n the matter of pictures, nicknacks, etc., there was no affectation of 'culture.' Aestheticism ... has not yet penetrated the negro home. ... The works of art are simple to the point of primitiveness, and pleasing in so far as they genuinely represent the taste of their owners." Yet Archer concluded 
that African American reproduction of American styles was usually so thorough that it actually rang hollow. For example, he indicated that

[w] hat troubled me throughout my domiciliary visits was the sense that (with one or two exceptions) these homes were not homes at all. ... They were no more homelike than the shopwindow rooms of the up-to-date upholsterer. If they were lived in at all, it was from a sense of duty, a self-conscious effort after a life of "refinement." They were, in short, entirely imitative and mechanical tributes to the American ideal of the prosperous, cultivated home (Archer 1910:162-163).

Ultimately, African Americans so seamlessly reproduced dominant material style that Archer interpreted it as exaggerated inauthenticity.

Many of Madam Walker's neighbors were certainly living in vastly different conditions than she, but social "respectability" was a complex blend of public behaviors, family lineage, community connections, and genuine material wealth. Most of the employees in Walker's backyard factory, for example, were not especially wealthy or from elite lineages, but many of them secured genuine status in the community. About 40 people working in the backyard factory were on the Walker Company payroll until 1928, when the operation and those employees moved from the backyard into the newly constructed neighboring Walker Building, which featured an Afrocentric art deco theater and professional offices, as well as the operations of the Walker Company. Virtually all of these employees were women. In 1923, for instance, 34 of the 38 people on the company payroll were women, including former laundresses and domestics, as well as some women from bourgeois backgrounds. The factory was managed by Alice Kelly, who along with lawyer Freeman Ransom was perhaps Madam Walker's closest colleague. Kelly had been a matron at the Eckstein-Norton Institute, where she taught Latin and supervised the students' domestic training at the industrial education school near Louisville, Kentucky. The school was established in 1890 in Cane Spring, Kentucky, and Walker probably first met with her in January 1910 during a visit to the campus (Bundles 2001:100). In August 1911 Kelley visited Walker in Indianapolis, and in December she returned to hold a reception for Walker's daughter in the North West Street home (Indianapolis Star 1911c:34, 1911d:34).
Shortly after the school closed in 1912 (Parrish 1948:289), Kelly joined the Walker Company and became the factory's forelady as well as Madam Walker's personal tutor, instructing her in speech, etiquette, and grammar.

Most of Walker's company was staffed by women from modest backgrounds, some of whom secured some foothold in respectable society. Violet Davis Reynolds, for instance, was a former Eckstein-Norton Institute student who came to Indianapolis in 1914 on Alice Kelley's recommendation. Davis began boarding in Walker's home, became the company's stenographer, and in 1960 was still the executive secretary of the Walker Company. Marie Brooks Overstreet came to Indianapolis in about 1920, and she was a bookkeeper for the company into the 1930s. Flossie Glover was born in South Carolina in 1897 and was also working for the Walker Company as a stenographer by 1920 . Glover moved to Indianapolis by 1917, living with her sister Alice and Alice's husband, lawyer Robert Brokenburr, who represented Madam Walker along with Freeman Ransom. Two Ransom relatives and another of Flossie Glover's sisters worked in the factory in the 1920s. The most distinctive story was that of Parthenia Rollins, who came to work for the Walker Company around 1915, when she was already roughly 75 years old. Enslaved in Kentucky as a child, Rollins became Walker's cook nearly a half century after her emancipation. When Walker died in 1919 Rollins was named as a beneficiary in the will and continued to receive a salary until her death in 1952, when she was buried at the expense of the Walker Company.

Walker was like many of her neighbors and employees who had emerged from genuine poverty with little or no formal education yet aspired to secure a foothold in "respectable" society. Exactly what constituted such respectability, though, was ambiguous. St. Clair Drake and Horace Cayton's 1945 Black Metropolis painted an especially complex picture of Chicago's African American elite that probed the definition of respectability and assessed the ways affluence, poverty, and status were defined within the community. Drake and Cayton's analysis was one of the most thorough 20th-century studies of African American affluence, but they accorded ostentatious material wealth relatively little importance. They instead saw class standing 
most clearly linked to "respectability," arguing that "these upper-class people took 'respectability' for granted. They were concerned with 'refinement,' 'culture,' and graceful living as a class-ideal" (Drake and Cayton 1945:531). The material forms taken by such respectability revolved around domestic goods, because the "upper class is 'home-centered,' stressing an ordered and disciplined family life" (Drake and Cayton 1945:531). This elite home discipline was reflected in "extreme emphasis on 'maintaining a good home,' with fine furniture, linen, glassware, china, and silver much in evidence" (Drake and Cayton 1945:530).

Drake and Cayton did not evade recognition of poverty, but they did not detach it from African American affluence and those they defined as "middle class," a cross-class approach that ultimately dissected complicated class relations and tensions within black Chicago. They argued that the Great Migration's flood of Southern newcomers displaced the city's previous 19th-century elite, who had been bound by "social ritual and a concern with "culture"" and were formed by families that had long lived in Chicago (Drake and Cayton 1945:543). Drake and Cayton (1945:543) saw 20th-century migrants (like Madam Walker and many of the women who worked for her) as a stream that "resulted in the expansion of the business and professional classes who gradually displaced the Old Settlers as the "cream of society." "That interpretation complicated established analyses of the Great Migration, recognizing that it delivered entrepreneurs who became affluent and ascended to elite status, and was not simply composed of the South's most impoverished citizens who continued to be marginalized in the urban North.

Drake and Cayton believed that social standing had relatively little to do with relative affluence and was instead invested in social discipline. They argued that for the elite "[i]t is not poverty that outrages their sensibilities, but lack of public decorum - what they call 'ignorance,' 'boisterousness,' 'uncouthness,' 'low behavior'" (Drake and Cayton 1945:559). Drake and Cayton (1945:559) concluded that the elite saw such behaviors as "a drag on The Race," intimating that the elite saw themselves yoked to other African Americans by race. This had been a common complaint of black elite since the 19th century, but it inelegantly evaded recognizing the privileges of wealth and implied that "respectable" behaviors and standing were not dependent on affluence. In this sense, Black Metropolis painted an interesting picture that vested most status symbolism in social discipline but never ignored how status was determined by the concrete realities of relative affluence. For instance, Drake and Cayton argued that a stratum of African American Chicago might be termed middle class, defined by "the way people spend their money, and in public behavior [emphasis in original]" (Drake and Cayton 1945:662). This group had genteel ambitions but was constrained by factors including poverty, education, or social associations, and that definition might well describe many of the women who worked for Madam Walker. For this group Drake and Cayton did emphasize at least one dimension of materiality. For the middle class, "'having a nice home' usually becomes a consuming passion - nearly always a primary interest" (Drake and Cayton 1945:663). They argued that, especially for Southern migrants, "real estate is a potent symbol of stability and respectability" (Drake and Cayton 1945:663), but as with their assessment of elite standing they did not accord ostentatious consumption a particularly significant position.

Drake and Cayton did identify a circle of newly affluent African Americans who were intensely committed to conspicuous consumption, but this materialism was among the central reasons they did not qualify as "respectable." Their materialism was focused primarily on entertaining, throwing private parties and formal dinners featuring rare foods and fine clothing, and the apparent desire for public material visibility was viewed warily by Chicago's established African American upper class. Drake and Cayton (1945:550) argued that these affluent African Americans who had embraced conspicuous materialism "have the money, but they are keenly aware that there are some things that won't buy." They implied that wealth alone could not buy some measures of educational, social, and family status.

The symbolic threat African American consumption actually posed was quite different from one community to the next. Occasionally, though, African American materialism clearly posed more than a symbolic threat to white privilege, and these conflicts almost always revolved around moments African Americans 
began moving into what had formerly been exclusively white neighborhoods. Jesse Binga, for instance, moved to Chicago in 1893, opening an African American bank in 1908 and managing real estate, which made him quite wealthy. Binga purchased a home in a white neighborhood, and it was bombed five times in the year spanning February 1918 to February 1919 alone (Chicago Commission on Race Relations 1922:125,536). A 1920 Chicago newspaper article rooted such violence in African Americans' propensity to conspicuous materialism and the inference that such consumers were advocating for full civil rights. The paper argued that "[t]he Negroes innate desire to 'flash,' to live in the present, their inordinate love for display has resulted in their being misled by the example of such individuals as Jesse Binga. ... In their loud mouthing about equality with the whites they have wormed their course into white neighborhoods, where they are not wanted and where they have not the means to support property" (Chicago Commission on Race Relations 1922:122; Drake and Cayton 1945:178-179). African Americans' expensive dining goods or clothing rarely produced violence, but advances into formerly white neighborhoods were greeted by violence throughout urban America. Drake and Cayton (1945:206) argued that over 30 years after Binga's home was bombed the rule remained that "Negroes, regardless of their affluence or respectability, wear the badge of color. They are expected to stay in the Black Belt."

\section{"A Degree of Extravagance": African American Affluence and Ambition}

Madam Walker's Indianapolis home was utterly restrained in comparison to the two New York homes she lived in over the final three years of her life. In 1916 Madam Walker moved from Indianapolis to Harlem, though her business remained based in Indianapolis. Under the direction of African American architect Vertner Woodson Tandy, Walker remodeled a Harlem townhouse on West 136th Street, converting neighboring structures into one larger building with a newly installed Georgian facade. In 1917, she commissioned Tandy to design a massive mansion at Irvington-on-Hudson, a home into which she eventually moved in June 1918 (Bundles 2001:234). As the Irvington home neared completion, the New York Times (1917:SM4) indicated that "[p]lans for furnishing the house call for a degree of extravagance that a princess might envy. There are to be bronze and marble statuary, sparkling cut glass candelabra, paintings, rich tapestries, and countless other things which will make the place a wonder house." For instance, the paper noted that "Mme. Walker likes music," describing the complex piping system that channeled the home's organ music into every room (New York Times 1917:SM4). The mahogany bedroom suite was ivory-enameled, ceiling murals were found throughout the house, a book dealer counseled her on a massive collection of books for her new library, and statuary was scattered throughout the home. The mansion came to be known as Villa Lewaro, an acronym using the first two letters of daughter Lelia Walker Robinson's names. Her daughter eventually auctioned the home and its contents in 1930, when a visitor indicated "the walls are lined with handmade tapestries, bronze and ivory statuettes, and a large figure of a jaguar springing at a horse" alongside a massive collection of ivory (New York Times 1930:27).

Keen to deflect criticism that the house was overly extravagant, Madam Walker wrote her lawyer Freeman Ransom that "Villa Lewaro was not merely her home, but a Negro institution that only Negro money had bought" (Bundles 2001:235). She argued that the mansion was intended as a statement "to point to young Negroes what a lone woman accomplished and to inspire them to do big things." In 1910 Scottish visitor William Archer penned a prescient African American travelogue that wrestled with this symbolic role of wealth in African America. Archer acknowledged that in his travels he witnessed significant wealth among African Americans, and he recognized the profound symbolic importance of that affluence. He suggested that in recurring tours of grand African American homes, businesses, and public spaces " $[\mathrm{t}]$ here was something impersonal about it all. It was not the men but the race who boasted. It was not 'I,' nor 'he,' but 'we'" (Archer 1910:159-160). Archer suggested that such wealth was greeted with widespread African American pride, much as Madam Walker hoped.

The genuine transformative potential of black consumption was disputed by African Americans from the turn of the century onward. A 1941 study, for instance, concluded that the "purchase 
of expensive automobiles is certainly exaggerated among colored groups ... [because] these economic symbols have higher social value than in most white communities" (Davis et al. 1941:243). The 1941 assessment suggested that "[m]ost of the symbols of status in our society are denied to colored persons. In the South and in most areas of the North, even those colored people who have the economic means are not allowed to share in most of the activities which serve as symbols of economic and social status for the parallel white groups" (Davis et al. 1941:244). This position was skeptical of the genuine power of black consumption, suggesting that even when they were in possession of these most desirable commodities blacks were still denied the citizen rights that for white consumers went with them.

Madam Walker certainly did not refute the commitment to African American wealth as a show of consumer and civic citizenship, but her simultaneous embrace of consumer affluence and unwillingness to ignore structural impoverishment foresaw the direction that was taken in African American consumer activism from the Depression onward. By the 1930s an increasing number of African Americans came to see laissez-faire capitalism as structurally committed to racially based impoverishment and unlikely ever to surrender racist and class privileges willingly. Increasingly fewer African Americans were willing to tolerate poverty or see consumer materialism as a path to black citizenship. In 1936, for instance, Ralph Bunche (1936:65) argued that New Deal programs targeted an ambiguously defined middle class, which was "captivated by the lure of the American Dream," without addressing structural injustices, concluding that "the Negro middle class exists, in the main, only psychologically." By 1957 Franklin Frazier (1957:26) launched an even more devastating attack on African American materialism, arguing that a black middle class had "accepted unconditionally the values of the white bourgeois world: its morals and its canons of respectability, its standards of beauty and consumption." It is not chance that many African American civil-rights protests were staged in public consumer spaces, striking blows for consequential consumer privileges and citizen rights alike in one move.

Affluence, Poverty, and the Color Line
Madam Walker was among the many African Americans who viewed their affluence as a demonstration of bourgeois ambition in the face of racism, but their affluence took much of its symbolic power from the ideological foil of poverty and simplistic ideologies of wealth as whiteexclusive. Poverty sometimes loomed in such discourses as a confirmation of certain African Americans' suitability to middle-class standing; in other hands, it served as a rhetorical rallying point that championed African American solidarity; and in still other hands it fueled a genuine commitment to eradicating the impoverishment inflicted on many African American communities.

Poverty operated in these discussions as both a material reality and an ideological representation, and both profoundly influenced the way in which African American wealth was defined by white and black observers across classes. On the one hand, poverty was a concrete material experience, and few African Americans had the opportunity to ignore impoverishment and its clear basis in racism. The proximity of the wealthiest and poorest members of the African American community alongside each other on North West Street underscores how difficult it was for African Americans to ignore the connection between racism and impoverishment or reduce poverty simply to a rhetorical abstraction. In this context, black wealth often was viewed as a refutation of racist stereotypes-especially those linked to poverty-and an entreaty for full consumer citizenship. On the other hand, poverty was an ideological representation that was wielded to discipline the residents along North West Street as they and other Americans measured themselves against ambiguous material and social norms. Many visions of African American wealth aspired to an idealized notion of affluence that was secured by extremely few Americans of any background, romanticizing the genuine opportunities available to any citizen and perhaps overestimating the power of African American consumption to unseat racism.

By any measure Madam Walker was exceptionally wealthy, but any assessment of African American affluence was inevitably tied to the color line and never utterly distanced from black poverty stereotypes. Rather than focus on purely economic measures of wealth reflected in a material assemblage, Madam Walker's consumption 
demonstrates how affluence and poverty were utterly social concepts embedded in class structure, gendered ideologies, race, and a host of contextually specific factors. For Madam Walker, much of the social meaning of her affluence came from its implicit contrast to poverty, and in the case of Walker and many newly wealthy African Americans their affluence was a model of respectability for their African American neighbors, reproducing dominant genteel ideologies while their consumption unabashedly embraced conspicuous wealth.

The power of that model - and the purview of racism-was clear in December 1915, when Indianapolis's African American YMCA passed an official decree imploring Walker to maintain her home in the city and not move to Harlem. The decree indicated that the members, "realizing the great loss her removal would be to the city and state, beg her to reconsider it and live always among us to the end that we may be conscious of and influenced by her beautiful and useful life she lives" (YMCA 1915); their entreaty failed, though. In February 1915 Walker had been levied an additional admission charge at the Isis Theatre in Indianapolis, a strategy that was typical of the everyday indignities targeting African American residents, including its most wealthy member. Walker filed a lawsuit arguing that "she is of African descent, and a member of what is commonly called the colored race: That when she applied for a ticket and admission to said show, she was clean, sober, neatly dressed, and orderly, that she was ready and willing at all times to comply with all lawful and reasonable rules and regulations" (Indianapolis Star 1915:7; Suit of the Central Amusement Company 1915). Walker decided that despite her wealth she could not tolerate or evade the everyday racist indignities she experienced in Indianapolis. Her move to Harlem confirmed that no degree of affluence could evade racism, binding her to the many poor African Americans throughout the nation.

\section{Acknowledgements}

This research was made possible by a Multidisciplinary Undergraduate Research Institute Grant from Indiana University-Purdue University, Indianapolis. Thanks to Cynthia Bates, A'Lelia Bundles, Dave Gadsby, Ryan Gray, Chris Matthews, Wilma Moore, Thomas Ridley, Suzanne Spencer-Wood,
Amy Warner, and Glenn White for their help throughout the Walker site research and fieldwork. These folks bear no responsibility for any of the shortcomings of the final paper.

\section{References}

ArCher, William

1910 Through Afro-America: An English Reading of the Race Problem. E. P. Dutton and Company, New York, NY.

BAKER, RAY STANNARD

1973 Following the Color Line: An Account of Negro Citizenship in the American Democracy, reprinted from 1904 edition. Corner House, Williamstown, MA.

Bunche, RALPh J.

1936 A Critique of New Deal Social Planning as It Affects Negroes. Journal of Negro Education 5(1):59-65.

Bundles, A'Lelia

2001 On Her Own Ground: The Life and Times of Madam C.J. Walker. Scribner, New York, NY.

Chicago Commission on Race Relations

1922 The Negro in Chicago: A Study of Race Relations and a Race Riot. University of Chicago Press, Chicago, IL.

Davis, Allison, Burleigh B. Gardner, and Mary R.

GARDNER

1941 Deep South: A Social Anthropological Study of Caste and Class. University of Chicago Press, Chicago, IL.

Divita, James J.

1994 Demography and Ethnicity. In The Encyclopedia of Indianapolis, David J. Bodenhamer and Robert G. Barrows, editors, pp. 51-60. Indiana University Press, Bloomington.

Dossett, Kate

2009 "I Try to Live Somewhat in Keeping with my Reputation as a Wealthy Woman": A'Lelia Walker and the Madam C.J. Walker Manufacturing Company. Journal of Women's History 21(2):90-114.

Drake, St. Clair, and Horace R. Cayton

1945 Black Metropolis: A Study of Negro Life in a Northern City. University of Chicago Press, Chicago, IL.

Du Bois, W. E. B.

1908 The Negro American Family. Atlanta University Press, Atlanta, GA.

DUDLEY, TARA

2006 Setting the Ideal African-American Interior: The Walker Residences and Salon in New York. Studies in the Decorative Arts 14(1):80-112.

FITTS, RoBert K.

2002 Becoming American: The Archaeology of an Italian Immigrant. Historical Archaeology 36(2):1-17.

FraZier, E. FrankLin 
1957 Black Bourgeoisie. Free Press, New York, NY.

Gaines, KeVIn K.

1996 Uplifting the Race: Black Leadership, Politics, and Culture in the Twentieth Century. University of North Carolina Press, Chapel Hill.

INDIANAPOLIS STAR

1911a Record of Transfers. Indianapolis Star 6 May:5. Indianapolis, IN.

1911b News of Colored Folk. Indianapolis Star 2 July:34. Indianapolis, IN.

1911c News of Colored Folk. Indianapolis Star 6 August:34. Indianapolis, IN.

1911d News of Colored Folk. Indianapolis Star 24 December:34. Indianapolis, IN.

1915 News of Courts. Indianapolis Star 9 April:7. Indianapolis, IN.

JOURNAL OF NEGRO HISTORY

1919 Documents: The Proceedings of a Migration Convention and Congressional Action Respecting the Exodus of 1879. Journal of Negro History 4(1):41-92.

KornBLith, Gary J.

1985 The Craftsman as Industrialist: Jonas Chickering and the Transformation of American Piano Making. Business History Review 59(3):349-368.

Leininger-Miller, Theresa A.

2000 New Negro Artists in Paris: African American Painters and Sculptors in the City of Light, 1922-1934. Rutgers University Press, New Brunswick, NJ.

NEW YORK TIMES

1917 Wealthiest Negro Woman's Suburban Mansion. New York Times 4 November:SM4. New York, NY.

1930 Villa Lewaro Art to Go at Auction. New York Times 29 November:27. New York, NY.

1932 Villa Lewaro Sold to Fraternal Body. New York Times 26 February:36. New York, NY.

Ovington, Mary White

1911 Half a Man: The Status of the Negro in New York. Longmans, Green, and Company, New York, NY.

PARrish, C. H., JR.

1948 Negro Higher and Professional Education in Kentucky. Journal of Negro Education 17(3):289-295.

\section{RECORDER}

1910 Rooms to Let. Recorder 10 December:4. Indianapolis, IN.

Roell, Craig H.

1994 The Piano in the American Home. In The Arts and the American Home, 1890-1930, Jessica H. Foy and Karal Ann Marling, editors, pp. 85-110. University of Tennessee Press, Knoxville.

Scott, Walter Dill

1917 The Psychology of Advertising. Small, Maynard, and Company, Boston, MA.
Suit of the Central Amusement Company

1915 Suit of the Central Amusement Company. Madam C.J. Walker Papers, Indiana Historical Society, Indianapolis $<$ http://images.indianahistory.org/cdm4/document .php?CISOROOT $=/ \mathrm{m} 0399 \&$ CISOPTR $=156 \&$ REC $=9 \&$ CISOSHOW $=152>$. Accessed 15 August 2011.

ThornBrough, EMma Lou

2000 Indiana Blacks in the Twentieth Century. Indiana University Press, Bloomington.

YMCA

1915 Madam CJ Walker YMCA Resolution. Madam C.J. Walker Papers, Indiana Historical Society, Indianapolis $<$ http://images.indianahistory.org/cdm4/document .php?CISOROOT $=/ \mathrm{m} 0399 \&$ CISOPTR $=156 \&$ REC $=9 \&$ CISOSHOW $=152>$. Accessed 15 August 2011.

Paul R. Mullins

DepartMENT OF ANTHROPOlOGY

INDIANA UNIVERSITY-PURDUE UNIVERSITY, INDIANAPOLIS

Cavanaugh Hall 413B

INDIANAPOLIS, IN 46202

Modupe Labode

Departments of History and Museum Studies

INDIANA UNIVERSITY-PURDUE UNIVERSITY, INDIANAPOLIS

Cavanaugh Hall 420

INDIANAPOLIS, IN 46202

LEWIS C. JONES

Department of Anthropology

INDIANA UNIVERSITY

Student Building 130

701 E. KiRKwood Avenue

BloOMINGTON, IN 47405

Michael E. Essex

Department of Anthropology

INDIANA UNIVERSITY-PURDUE UNIVERSITY, INDIANAPOLIS

Cavanaugh Hall 413

INDIANAPOLIS, IN 46202

Alex M. Kruse

Archaeology General Office

EDB 9635

8888 UnIVERSITY DRIVE

BURnABY, BC V5A 1S6

CANADA

G. Brandon MunCy

Department of Counseling and Educational PSYCHOLOGY

SCHOOL OF EDUCATION

INDIANA UNIVERSITY

201 N. Rose Avenue, Suite 4000

Bloomington, IN 47405-1005 